\title{
Identity in Sport Teams
}

\author{
Cristina Zucchermaglio, Francesca Alby ${ }^{*}$ \\ Sapienza University, Rome, Italy. \\ Email: francesca.alby@uniroma1.it \\ Received February $2^{\text {nd }}, 2011$; revised May $4^{\text {th }}, 2011$; accepted June $2^{\text {nd }}, 2011$.
}

\begin{abstract}
In this paper we analyze identity in a soccer team using a discursive perspective, in which individual psychological functioning is considered to be built in and through social interactions within groups. Analysis is based on naturally-occurring interactions that were audio recorded during technical meetings before and after the match. The data were collected within an ethnographic investigation of an Italian soccer team carried out over a two-month period. The results show that the team's members made rhetorical use of a complex repertoire of their own and others' social identities, and that two main variables influenced the use of social identity markers: a) the role of the speakers (in particular the "power" role of the coach); b) the result of the match around which the interactive discourse revolved. Against this background, we discuss how narratives and identity positionings were used to achieve specific goals and to perform specific actions, such as the planning of future matches and the interpretation of victories and defeats.
\end{abstract}

Keywords: Identity, Group, Discursive Psychology, Sport

\section{Introduction}

To date the "psychology of sport" has had a mostly psychophysiological or cognitive interest in studying the athlete from an individual point of view (see also Hogg \& Hardie, 1991; Hogg, 1996). Although groups are the basis of team sports, they have certainly received less attention as specific social phenomena. The majority of studies on sport teams always use 'individual' instruments such as questionnaires or measurement scales of attitudes and behaviours of athletes or coaches.

Identity in sport teams has been studied from two main perspectives: a) an individual one, most widespread among sport and exercise psychologists, which focuses on identity as a cognitive and stable dimension of the individual (see for example Killeya-Jones, 2005; Cox \& Whaley, 2004; Anderson, 2004; Schmid \& Seiler, 2003) using standardized scales, tests and interviews to 'measure' such an identity (Curry \& Weaner, 1987); b) a social perspective, most widespread among sport sociologists and anthropologists, which focuses on wider social variables and contextual features (such as cultural, national, political issues) (Mac Clancy, 1996; Robert, 1999) using narrative and ethnographic methodology (see Thiele, 2003; Sparkes, 1996, 1997, 2002).

In this paper we adopt a third perspective (cultural and discursive psychology), in which individual psychological functioning is considered to be built in and through social interactions within groups.

Very few studies have adopted a conversational-discursive approach to analysis of how identity and the related processes of identification, differentiation and categorisation in sport groups are carried out discursively (for example Finlay \& Faulkner, 2003; Locke, 2004 use a conversational methodology to analyse individual interviews with athletes), and little empirical research on these phenomena has used as its empirical data transcripts of interaction/conversation among members of sport teams.
In what follows we present this type of analysis, which was conducted on identity negotiation processes in the discursive interactions of an Italian soccer team.

\section{Identity, Participation and Discourse}

Cultural psychology, particularly in its discursive thread (Cole, 1995; Billig, 1987; Edwards, 1998), has laid the foundations for the contextual and rhetorical study of psychological constructs. It emphasises the importance of the social and discursive context of interaction as the locus for the construction and negotiation of individual and social identity (Muhlhausler \& Harré, 1990; Bruner, 1990; Goodwin \& Goodwin, 2003). As its units of psychological analysis, this perspective uses communities of practice (Wenger, 1998) and all the 'natural' interactive situations in which the construction and negotiation of shared meanings (also about identity) can be identified by linking interaction and grammar. Here "grammar is part of a broader range of resources - organizations of practices, if you will-which underlie the organization of social life" (Schlegoff, Ochs, \& Thompson, 1996: p. 2), and social interaction in particular.

Conversational research shows that self and social categorisations are situated outcomes of negotiation practices occurring during social-discursive interactions with others, rather than being static, cognitive traits of individual identity (Antaky \& Widdicombe, 1998). As Edwards (1998: p. 17) writes: “...self categorizations, like categorizations of other people and of everything else, are discursive actions done in talk, and performative of talk's current business". On this view, identity is "something that people do which is embedded in some other social activity, not something they 'are"' (Widdicombe, 1998: p. 191).

Hence the discursive manipulation of one's own identity or those of others appears to be functional to achievement of specific rhetorical objectives. These rhetorical strategies high- 
light that identities can become important negotiation content among members of a group, rather than being a stable characteristic of their identity - an "a priori" of discourse in interaction (in this regard see also the concept of "positioning": Harré, 1989; Harré, \& Van Langenhove, 1991). Consequently, as Perkins (1994: p. 3) puts it, identity should not be considered as "a pure and stable unit but as a sum and multiplicity of acts of participation".

In their seminal work, Antaki and Widdicombe (1998: p. 3) described five aspects characterising the discursive study of identity:

- to have an identity is to be cast into a category with associated features;

- such casting is indexical and occasioned;

- it makes the identity relevant to the interactional business going on;

- the force of 'having an identity' is in its consequentiality in the interaction;

- all this is visible in people's exploitation of the structures of conversation.

Sacks's works (1992) on identity negotiation, too, have shown how speakers choose what relevance to give to identity according to the activities around which the interaction is built (rhetorical objectives) by choosing particular categories with which to link identity. Sacks stresses that these choices are indexical (that is, defined by the terms used to mark the belonging categories to give salience), and occasioned, meaning that there is a particular context where the categories chosen assume relevance.

The concern has therefore been to analyse how the participants in socio-discursive interactions create, propose and use specific identity categories in order to perform specific rhetorical actions. Discourse is pervasively rhetorical (Billig, 1987), in fact, and within ongoing discourse it is always possible to choose among different ways to describe one's own identity and those of others: "situational variability is an intrinsic characteristic of discourse and social actions in the sense that discourse always performs actions, it is constructed for specific occasions, thereby reflexively constituting the meanings of those occasions, and it is oriented rhetorically" (Edwards, 1998: p. 18).

As interactive resources, each participant has different identities to show, and which to make salient in order rhetorically to exhibit and position the self and the other. The choice among these options is guided by social factors, such as the relationship between the participants, their roles, and the object of the interaction (Ochs, Gonzales, \& Jacoby, 1996; Fasulo \& Zucchermaglio, 2002).

Methodologically, therefore, identity positioning is framed as a discursive practice in which all members of the interacting group participate. This requires consideration of the central role performed by the discursive co-construction of joint narratives in which all members position both themselves and simultaneously the others.

The cultural approach therefore enables study to be made of rhetorical and strategic positionings not only as the individual moves defined by Harrè and van Lagenhove (1991), but also as the dynamic and social outcomes of forms of participation in the activities of specific groups and communities.
These forms of participation in "social structures" should also be interpreted in light of the interplay among the positionings and identity constructions of the participants in the interaction. Different levels of participation in the community are activated by dynamic and strategic positionings which should be interpreted as collective dynamics that refer to the community's ongoing activities. As Goffman (1959) notes, also the participants' representations of the setting are the product of integrated collective activities, rather than being isolated individual interpretations by each member: "the definition of the situation by a particular participant is an integral part of a projection which is activated and maintained by the close cooperation of several participants" (Goffman, 1959: p. 95).

In this framework, identity is a resource that participants are able to use during the interaction in a strategic way (Zimmerman, 1998), but opportunities to use different (even possible) identities are context-related. In other words, the indexical choice about one's own positioning is not an individual process which takes account of the social context. Rather, the context itself plays an active role not only in allowing some possible choices to be used by participants but also in determining the access of individuals to the positioning process.

Antaki and Widdicombe (1998) suggest that the concept of "procedural consequentiality" can be used to make joint consideration of both the relevance acquired by the identity in the context of interaction and the ways in which this relevance contributes to defining/constructing the interactive context itself.

Identities are accordingly studied as forms of social practices of participation in groups. This crucial epistemological choice has major consequences in terms of research methodology. The data considered to be relevant are the interactive practices-discursive, visual and material-performed by social actors in real settings. Social interactions are considered essential for analysis of how identity is socially constructed and rhetorically used in groups - in sport teams as well.

\section{Identity in a Soccer Team: Ethnography and Discursive Data}

The "soccer team" group examined by this paper is highly distinctive (in the sense that its structure is the basis of all group sport activity) because it is conditioned by rather unpredictable work results (its activity is basically "sport-game-work") and because this activity has a rather important social meaning.

Thorough ethnographic analysis carried out over a two-month period (Zucchermaglio, 2005) revealed a series of aspects and characteristics regarding the functioning of the "soccer team" group and identified the specific times in the team's weekly routine of greatest interest from the interactive and communicative point of view.

- The team was organised into small groups according to technical area (defence, midfield, attack and goalkeeping).

- There were other basic but external "groups", such as members of the coaching staff, the managers, the fans, and the club.

- The most communicative of the various interactions characterising the life of the "team" group, with respect to its 
more technical ${ }^{1}$ phases, was when the work done and the work to be done was planned and explained. This took place during the coaching sessions immediately following the weekly game (usually on a Tuesday).

In fact, the "team" group usually met at the first coaching session after the championship ${ }^{2}$ game in order to discuss the work done and to plan the next week of work. The meeting was held in the changing rooms or in an area of the coaching field. There was then another interactive encounter when a sort of general review of the work was conducted. This preceded the official game by about two hours and took place in a room at the club's headquarters.

Owing to these characteristics, which were particularly functional for our research objectives, we decided to observe two interactions following two games with opposite results (a victory and a defeat) and a pre-game situation. All the players, the manager, the athletic trainer, the goalkeeping coach and the assistant coach always participated in the interactions observed. ${ }^{3}$

The three interactions observed were audio recorded for a total of around two hours of conversation; and they were completely transcribed using Jefferson's method (Jefferson, 1989). The entire corpus consisted of 788 turns of conversation distributed non-homogeneously among the three observations. ${ }^{4}$

\section{Identity in Action: Groups, Power and Narrative}

This corpus of data has already subjected to a preliminary analysis which revealed a more complex and dynamic situation than the simple In-group/Out-group pattern, with the emergence of a plurality of "groups" in the interactive discourse of the soccer team's members (cfr. Zucchermaglio, 2005). In particular, it has been shown that the team's members made rhetorical use of a complex repertoire of their own and others' social identities, and that two main variables influenced the use of social identity markers: a) the role of the speakers (in particular the "power" role of the coach); b) the result of the match around which the interactive discourse revolved.

This latter result is particularly interesting because it shows that groups are made to "exist" in discourse in order to achieve specific rhetorical objectives. The manipulation of social identities in post-victory and post-defeat interactive situations showed not only that social identities are many (in the sense that each of us has several of them) but above all that the choice of which identity to make salient in discourse is rhetorically oriented.

In the interactive situation following a defeat, the markers of own and others' social identities were used much more frequently than they were in a post-victory situation. This is indicative that the players and the coach felt a strong need to differentiate the social identities of groups or subgroups to which specific blame could be attributed in the event of defeat.

\footnotetext{
${ }^{1}$ The "match" situation was not significantly communicative except for the interval between the two halves. However, the researcher did not have access to the changing rooms at official times because they were off limits and Federation security measures forbade it.

${ }^{2}$ Between the Sunday game and the first practice session there was a day of rest (Monday).

${ }^{3}$ There were 26 participants; 20 were speakers.

${ }^{4}$ The first encounter comprised 616 turns, the second 76 turns, and the third 96 turns.
}

Sport team members segment their own and others' social worlds to achieve their rhetorical goals. By placing themselves and others in "groups" they present and share a certain representation/interpretation of reality. Research shows that members seek to identify the specific contributions made by technical areas to defeats (for example: "it's the fault of the defenders..."), while in the case of victory there is no specific analysis of behaviour on the pitch, with the merit being attributed indiscriminately to the team as a whole (for example: "It's the merit of the team"). It is also important to stress that these "proposals" of positioning should be shared by the other members if they are to have a rhetorically structuring effect on the interactive discourse (for more detailed analysis of these results, see Zucchermaglio, 2005).

Against this background, which is already interesting for the light that it sheds on the rhetorical manipulation of the social identities arising in the discourses of this professional soccer team, in what follows we shall conduct more detailed analysis of the relation between the construction and use of specific identity positionings and the rhetorical actions performed through these positionings by the members of the sport group, doing so in relation to the interactive features of the three meetings analyzed.

\section{Team Meetings as Narrative Templates}

As said, the interactive data on which we base our analysis concern three team meetings. Specifically, meeting T1 took place after a victory in the championship, meeting T2 just before a match, and meeting T3 two days after a defeat. All the players, together with the manager and the coach, were present at the meetings. The temporal location of the meetings with respect to the matches (and their outcomes) makes them highly diversified in regard to the actions (also those of categorization and identity positioning) performed during them.

Meeting T1 was held after a victory and it mainly took the form of a collective brainstorming session. This team identity (constantly evoked during meeting T1) was most functional to producing collective metacognitive organized reflection guided "pedagogically" by the manager and the coach.

Meeting T2 was held just before a match, and its action centred on forecasting the likely course of the game. The narratives produced and the patterns of participation by the team members were functional to constructing imaginary scenarios intended to facilitate and coordinate the team's future collective action on the pitch (on this see Fasulo, Zuccchermaglio, 2008).

Meeting 3 took place after a defeat. Compared with meeting T1 (held after a victory), when the group conducted more general analysis of the team's behaviour, on this occasion the talk was about the game lost, and both the opposing players and the team were marked in identity terms. For example (see excerpt 10 ), the manager made much more specific reference (also with names and surnames) to individual players, and also to "critical" game behaviours which had led to defeat ("we had an extra man in midfield rather than an extra man in defence").

\section{Who are "We"?}

A strong identity emergent from the community's/team's discourses is "we" as a social entity. We found several instances where this social identity was characterized, not by the 
use of specific social categories ("team", "player", etc.) or particular pronominal markers ("we"), but by a set of characterizations realized discursively through the description of the team's specific actions or properties (see on this Edwards, 1998). For example (see excerpt 11), the manager stresses that an important attribute of the team's identity, and which distinguishes its game behaviour (as well as the meanings of its defeats and victories), is that the players are "C1 people".

\section{Excerpt 11 (Meeting T3)}

13 ALL1: [((laughs)) if we were Juventus playing in C1, it's obvious we'd always win, but we're $\mathrm{C} 1$ people playing in $\mathrm{C} 1$ ! (0.8) so?

13 ALL1: [((ride)) se noi fossimo la Juventus che gioca in $\mathrm{C} 1$, è chiaro che dovremmo vincere sempre ma noi siamo gente di $\mathrm{C} 1$ che gioca in $\mathrm{C} 1$ ! (0.8) allora?

In another case (see excerpt 12), the manager uses the same mechanism of identity categorization for the team as a whole, his purpose being to cite and emphasise behaviour ("when some of our players were fouled, they looked at the referee ")that he deems unacceptable ("we haven't got the whistle, we go on to the pitch and we play"; "until you hear the whistle, get on with it").

The manager further underlined this injunction by pointing out the different behaviour of the opposing team (the one which had won the game; "I didn't see any Juve Stabia player complaining because we'd committed a foul and the referee hadn't blown his whistle").

Excerpt 12 (Meeting T3)

68 ALL1: when some of our players were fouled, they looked at the referee. (1.2) only those you saw (1.5) then I didn't see (1.0) Maurizio (0.8) tell me (1.8) What was IT SUPPOSED TO MEAN? (0.5) I told you during the week, especially Orazio, sometimes (0.2) or Misiti. (0.5) we haven't got the whistle, we go on to the pitch and we play. (0.2) a foul is at the discretion (0.2) of who's unfortunately (.) got the whistle in his mouth. (.) UNTIL you hear the whistle $(0.5)$ get on with it (0.2) bear with it, (1.8) but it isn't like that (2.2) but it isn't like that (0.5) I didn't see one of the Juve Stabia players(.) $\mathrm{h}$ complaining because we'd committed a foul and the referee hadn't blown his whistle $>$ if we'd got him to do it $<(1.5)$ $>$ we were there $<(0.5)$ we saw it together $(0.2)$ there were at least two of us not just one (.) so (0.2) can you explain this fact to me (3.5)

68 ALL1: qualche nostro giocatore quando subiva fallo guardava l'arbitro. (1.2) solo quanti ne hai visti (1.5) allora non ho visto (1.0) Maurizio (0.8) dimmi (1.8) PER SIGNIFICARE che cosa? (0.5) io ve lo dico anche durante la settimana specialmente a Orazio qualche volta (0.2) o a Misiti. (0.5) il fischietto non ce l'abbiamo noi noi andiamo in campo e giochiamo. (0.2) il fallo è a discrezione (0.2) di chi purtroppo (.) ha in bocca il fischietto. (.) FINO A CHE non si sente il fischio $(0.5)$ bisogna andarci dentro $(0.2)$ di sana pianta, $(1.8)$ però non è così (2.2) però non è così $(0.5)$ io non ho visto uno della Juve

\footnotetext{
'Serie $\mathrm{C} 1$ ' denotes a professional football league which does not cover the entire country (like the top two divisions of Serie A and Serie B) but is divided into three sections corresponding to the three geographical macro areas (North, Centre, and South) into which Italy is conventionally divided.
}

Stabia (.) h reclamare perché noi abbiamo fatto un fallo e non glielo ha fischiato $>$ sempre se glielo abbiamo fatto $<(1.5)$ $>$ eravamo li< $<(0.5)$ l'abbiamo visto insieme (0.2) $\underline{\text { siamo almeno }}$ in due non da solo (.) allora (0.2) mi sapete spiegare questo fatto (3.5)

Frequently evident in the discourses analyzed, especially during Meeting 2, are references to specific subgroups and sections of the broader team group (for detailed quantitative analysis of these phenomena see Zucchermaglio, 2005). As we have seen, the salience and relevance of these subgroups were functional to future game scenarios, especially but not solely for the manager. Here, for example (see excerpt 13), player CEN1 imagines the form that the relation between himself (midfielder) and the two central defenders should take. Described in this fictional narrative are not only the technicalathletic behaviour 'expected' of the defenders but also their communicative behaviour ("Livio move up!"; "Livio take him").

\section{Excerpt 13 (Meeting T2)}

47 CEN1: according to me there should be: $(0.5)$ a good dialogue between: between the two centres ((i.e. the central defenders)) and me (.) I mean: [a-

48 ALL1: [continuous=fixed, $($.$) [fixed$

49 CEN1: [exactly when they (saw it) and one of them moves up, (.) $>$ and they tell me $<$ Livio move up! if (.) or: Livio get him (0.5)

50 ALL1: if they're in a bad way $(0.2)$

47 CEN1: secondo me ci dev'essere:: (0.5) un buon dialogo tra: tra i due centrali ((si riferisce ai difensori $))$ e me (.) cioè proprio: [un-

48 ALL1: [continuo=fisso, (.) [fisso

49 CEN1: [esatto quando loro (se la sono vista) e magari sale uno di loro, (.) > e mi dicono< Livio sali! se (.) oppure: Livio prendilo (0.5)

50 ALL1: se loro sono messi male (0.2)

References to specific subgroups (midfielders and defenders, but also to subgroups in the opposing team) serve to populate these future game scenarios with personages, and also to support their detailed, situated and dynamic (rather than generic, abstract and static) creation/animation so that future game behaviour is more closely shared.

For example, again during Meeting T2 (see excerpt 14), the manager propounds a fictional narrative of the 'if....then' type with respect to the upcoming game. If the team can keep the ball on the ground and move when the opposing midfielders or defenders have ball possession, the more the team's game behaviour will be positive and efficacious, also bearing in mind the specific identity characteristics of the opposing central defenders ("ball on the ground, it seems I can say that they're slow, right?").

\section{Excerpt 14 (Meeting T2)}

72 ALL1: so the more we keep the ball on the ground, (0.2) $<$ and move when the midfielders $>$ or the defenders have the ball and there's movement (.) the more the cut-offs will be. (.) and the more they get into difficulties (.) the more likely they'll be $(0.2)$ to commit fouls! (1.2) and so: create difficulties for the central defenders who are $(0.5)$ ball on the ground, it seems I 
can say that they're slow, right? (0.2) eh? (0.5)

72 ALL1: quindi più teniamo a terra sta palla, $(0.2)<\mathrm{e}$ ci muoviamo quando i centrocampisti $>$ o i difensori sono in possesso palla più c'è movimento (.) più ci sono i tagli. (.) e più questi possono andare in difficoltà (.) più questi gli possono (0.2) fare un fallo! (1.2) e quindi:: creare difficoltà per i centrali che sono $(0.5)$ palla a terra mi sembra che posso dire che sono lenti o no? (0.2) he? (0.5)

Playing an evidently important role in these "future" narrative constructs are the identity characteristics of not only the team, its sections and the players but also (all the more so because of the game's imminence) of their opponents, as we shall now see.

\section{...Depends on Them}

A general feature of all three meetings is that references to the team's identity and characteristics depend in situated and specific manner on the identity characteristics attributed by the speakers to the opposing team. For example (see excerpt 15), the manager describes a general feature of his own team's behaviour by citing the characteristics of the teams that it has played against. The team plays well against "those that have got something to say on the pitch" while it suffers (i.e. plays badly) against those which "don't play", "don't let you play" and teams "tailor-made for $\mathrm{C} 1$ ".

\section{Excerpt 15 (Meeting T3)}

1 ALL1: (...) THEN AFTER BATTIPAGLIA we started saying did you see that at Battipaglia, (.) Crotone stands out (.) and: (0.2) no Crotone is after- stands out: erm: Acireale, stands out (.) Gualdo (0.2) those teams that perhaps, (0.2) that (.) ((coughs)) don't play (.)

2 CEN1: CEN1: they don't let [us:

3 ALL1: [=let's say let's say they don't let us play. (0.8) we've analyzed =we've said $(0.2)$ probably against those that have something to say on the pitch $(0.2)$ we perhaps (.) we play better (0.5), against those that instead (0.5) let's call them, (.) TAILOR-MADE for C1, (0.2) we find it difficult because: they put: their fingers=they put: and: their feet=they put $(0.2)$ they don't let you play (1.2) and because most of the teams are like that, (1.5) what should we do (.) should we back down? (...)

1 ALL1: (...) POI DOPO BATTIPAGLIA abbiam cominciato a dire a hai visto mai che a Battipaglia, (.) viene fuori Crotone viene fuori (.) e: $(0.2)$ no Crotone è dopoIviene fuori: em: Acireale, viene fuori (.) Gualdo (0.2) quelle squadre che magari, $(0.2)$ che fanno (.) ((tossisce)) non giocano (.)

2 CEN1: CEN1: non ci consen[tono di:

3 ALL1: : [=diciamo ecco diciamo non ci consentono di giocare. (0.8) abbiamo analizzato=abbiamo detto (0.2) probabilmente con quelle che hanno qualcosa da dire sul campo $(0.2)$ noi forse (.) siamo più bravi $(0.5)$ con quelle che invece (0.5) chiamiamole pure, (.) TAGLIATE ad hoc per la C1, (0.2) si fa fatica perché: ti mettono: le dita $=$ ti mettono: e: i piedi=ti mettono (0.2) non ti fanno giocare (1.2) e siccome la maggioranza di squadre sono quelle proprio, (1.5) che dobbiamo fare (.) dobbiamo soccombere? (...)

The team's identity characteristics are therefore highly interdependent (and mobile), while the identities of its opponents differ according to the courses of action highlighted as significant. For example (see excerpt 16), a specific identity characteristic of the opposing team is marked by the manager (and given agency "for having made us suffer" and therefore play badly) in order to construct an attitude among the players: they must not brood on defeats; instead, they must confront each game without dwelling on the 'history' of previous matches and "starting over again".

\section{Excerpt 16 (Meeting T1)}

487 ALL1: (...) he was exemplary ((referring to a defender not among the speakers)) at the end of the game. (1.2) when he entered the changing room. (0.5) you didn't hear him but I did

CEN2: fuck off Crotone

ALL1: GOOD! (0.5) so he exorcized the last away game (0.2) $>$ He came in and he was mad as hell $<<$ FUCK OFF CROTONE $>$ (.) BECAUSE THEY'D GIVEN HIM A HARD TIME (0.2) or I don't know (.) I think it was an (.) outburst at$(0.2)$

CEN1: but not just to feel [better

ALL1: [for making him (.) suffer a game [that:

CEN1: [suffer in an increasing - on a path we were following

ALL1: [(it seems that you have to) start over again

CEN1: [but not just because of me, because of the team

ALL1: great [certainly

487 ALL1: (...) lui è stato emblematico ((si riferisce $a$ un difensore che non figura tra $i$ parlanti)) a fine gara. (1.2) quando È entrato negli spogliatoi. (0.5) voi non l'avete sentito io sÏ

CEN2: vaffan'culo Crotone

ALL1: BRAVO! (0.5) ha esorcizzato la trasferta passata (0.2) $>$ È entrato dentro incazzato nero $<<$ VAFFAN'CULO CROTONE > (.) PERCHE' L'HA FATTO VIVERE MALE (0.2) o di fatto non so (.) penso che quello era un (.) esternazione per- $(0.2)$

CEN1: ma non cioè non solo un fatto di vivere [meglio

ALL1: [per averti fatto (.) soffrire più di tanto una parti[ta che:

CEN1: [soffrire in una crescita che- e in un percorso che stavamo facendo

ALL1: [(sembra che uno deve) tornare daccapo

CEN1: [ma non solo legato a me legato alla squadra

ALL1: benissimo [certo

In order to reinforce this construct, the manager positively emphasizes ("Good") the exemplary behaviour of player CEN1, who on entering the changing room had explicitly "exorcized the last away game" (which had been a defeat).

\section{Who Belongs to the Team?}

It might seem relatively easy to distinguish between the players and the training staff on the basis of 'objective' features and roles. In fact, however, this identity distinction was often anything but clear-cut during the socio-discursive interactions observed. In the next example (see excerpt 17) player DIF1 speaks like a "coach" ("I saw a good team on form").

Excerpt 17 (Meeting T3)

36 DIF1: [=very intensely (0.2) I saw the game: Thursday 
despite $>$ all the incidents that happened, $<(0.2)>$ in short $<$ I saw a good team on form: perky, not to say that: $(0.5)$ which did: (0.5) I mean > even with certain tricks $<$ stuff, I mean always serious and all that $(0.2)$ [not that

36 DIF1: [=parecchio intensamente $(0.2)$ io ho visto anche la partita: giovedì nonostante $>$ tutte le vicissitudini che sono successe, $<(0.2)>$ insomma $<$ ho visto una squadra tonica bella: pimpante non è da dì che: $(0.5)$ che fa de: $(0.5)$ cioè $>$ anche certi scherzi < robba, cioè uno sempre serio tutto quanto $(0.2)$ [non è che

It is interesting how player DIF1 is legitimated in his discursive role by the manager as an expert player ("another of the veterans") made able by precisely this identity characteristic to produce a more specific representation ("the view from above") of the team's performance (see excerpt 18).

\section{Excerpt 18 (Meeting T3)}

39 ALL1: : [ALDO! ((CEN 2)) (1.5) ${ }^{\circ}$ another of the veterans $^{\circ}$ ((laughs) $)(0.8)$ also because Maurizio, (0.2) perhaps has a better understanding of $>$ what we can do $<$ because he's $(0.2)$ been up several times (0.2) a view from above therefore (0.5) he was $(0.2)$ involved but not $(0.8)$

39 ALL1: : [ALDO! ((CEN 2)) (1.5) un altro dei più vecchi ${ }^{\circ}$ ((ride)) (0.8) anche perché Maurizio, (0.2) ha una cognizione forse migliore di $>$ quella che possiamo avere noi< perché lui $(0.2)$ è stato alto diverse volte $(0.2)$ la visione da sopra quindi $(0.5)$ era $(0.2)$ coinvolto ma non $(0.8)$

This identity recognition thus enables the manager to legitimate the oldest player as able to contribute importantly to the analysis of what had happened during the defeat. It is also interesting that this legitimation is granted with respect to a new social identity marked by the pronoun "we" ("Maurizio perhaps has a better understanding of what we can do") and which puts the manager and the players less expert than DIF1 into a single group.

This mobility in social and personal identity positionings is also apparent in the following example (see Excerpt 19) where the coach assumes several such positionings within the same discursive exchange. He begins by speaking as an active member of the team group ("we were unlucky"; the opposition was really tough"; "intensity was lacking entirely"), almost as if he is a player and not a member of the technical staff whose task during meeting T1 was to write the findings of the brainstorming session on the blackboard. He resumes this role from turn 340 onwards ("now I want someone to take one of these terms ....").

\author{
Excerpt 19 (Meeting T1) \\ 328.PREP: we were unlucky. (2.0) very unlucky (0.2) \\ 329 ALL1: then (1.5) \\ 330 CEN2: it depends (0.5) \\ 331 DIF4: depends (1.2) depends (.) \\ $332 \operatorname{PREP}^{\mathrm{L}}$ : the opposition was really: tough \\ 333 DIF4: $[(\ldots \ldots .)$. \\ 334 CEN2: $[(\ldots \ldots .)$. \\ 335 DIF4: we made ten minutes \\ 336 PREP: intensity was lacking [entirely \\ 337 ALL2: [sh:]
}

338 CEN1: [but when? (6.5)

339 CEN2: $>$ then we hit the post $<(1.5)$ as if you can score a [goal on the post

340.PREP: [h: $(0.2>$ now $<$ (.)I want someone to take: one of these terms (.)in case eh, $(0.8)>$ I mean, someone has to play the advocate for $<($.$) these eliminated terms here. (0.5)$ please.

328.PREP: siam stati sfortunati. (2.0) molto sfortunati (0.2)

329 ALL1: poi (1.5)

330 CEN2: dipende Ò (0.5)

331 DIF4: dipende (1.2) dipende (.)

$332 \operatorname{PREP}^{\mathrm{L}}:$ l'avversario E stato proprio: tosto

333 DIF4: $[(\ldots \ldots .)$.

334 CEN2: $[(\ldots \ldots)$.

335 DIF4: = dieci minuti amm fatt nuie

336 PREP: 1 'intensi[t $\neq$ È mancata del [tutto

337 ALL2: [sh:]

338 CEN1: [ma quando? (6.5)

339 CEN2: > poi abbiam preso il palo $<(1.5)$ prendi se fai [gol sul palo

340.PREP: [h: $(0.2>$ adesso < (.) voglio qualcuno che recupera: qualche termine di questi (.). se $=$ è il caso eh, $(0.8)>$ cioè qualcuno che fa l'avvocato per $<$ (.) questi termini qui eliminati. (0.5) a favore.

Even more illuminating light is shed on this phenomenon of team group inclusion/exclusion by examples of 'linguistic shift' in the manager's speech (see excerpt 20) taken from Meetings T2 and T3. These illustrate how the manager's choice of specific verbal forms enable him to remain simultaneously 'within' and 'without' the group of players ("we should be- you should be"; "they played we played you played"; "we aren't able to play - you aren't able to play"; "there were ten of us there were ten of you"; "it's not that we- it's not that you had to work hard back there.".

Excerpt 20 (Meeting T2 e Meeting T3)

Meeting 2:

52 ALL1: [but (.) we should be- you should be good enough not to gift them with a man. (1.0) because then what happens $(0.5)<$ there's four of them $(0.2)$ plus one five, $(0.2)$ for three $>$ (1.8)

52 ALL1: [però (.) dovremmo essere- dovreste essere tanto bravi da non regalare un uomo. (1.0) perché poi che cosa succede $(0.5)<$ ce n'è quattro $(0.2)$ più uno cinque, $(0.2)$ per tre> (1.8)

Meeting 3:

1 ALL1: we were doing better, but I don't know (.) let's take it as we saw it. (0.8) they played we played $(0.5)$ you played $(0.5)>$ and you were better $<$ apart from (.) the victories, but also in your game play, understand? (0.5)

1 ALL1: stavamo meglio, non lo so però (.) prendiamoli per quello che abbiamo visto. (0.8) loro giocavano noi giocavamo $(0.5)$ voi giocavate $(0.5) \mathrm{h}>$ e siete stati superiori $<$ al di là $($. delle vittorie, ma anche come gioco espresso capito? $(0.5)$

7 ALL1: ah! (0.2) > so you said < Mister if (0.2) we play like we know how there's nothing there for anyone. The facts that sometimes (.) we aren't able to play- you aren't able to play as you know how (.)

7 ALL1: ah! (0.2) > allora tu mi hai detto < Mister se (0.2) giochiamo come sappiamo non ce n'è per nessuno. il fatto è che 
alle volte (.) noi non riusciamo a giocare- voi non riuscite a giocare come sapete (.)

23 ALL1: [but I go back to when there were ten of us when there were ten of you against Palermo (0.8) there were ten of you and they didn't get a single chance even playing (0.2) half an hour: (.) From the attack=in practice (............) (0.5) it's not that we had- it's not that you had to work hard back there.

23 ALL1: [e ma io rivado a quando eravamo in dieci eravate in dieci col Palermo (0.8) là eravate in dieci quelli non hanno avuto un occasione pur giocando (0.2) mezzora: (.) all'attacco=in pratica (............) (0.5) non è che abbiamo- non è che avete faticato là dietro.

These (very frequent) examples signal that the manager's identity constantly oscillates between being 'a team member' (and thereby closely identifying with the group as a whole, the players and the coaching staff) and being a member with a particular status able to detach himself from the team in order to furnish efficacious guidance and supervision - a distinction reiterated shortly afterwards during Meeting T3 (see excerpt 21).

Excerpt 21

21 ALL1: : [e (...) me as the manager (.) and I hope (0.2) you as the players, (.) have different points of view. (...)

21 ALL1: : [e (...) io che faccio l'allenatore (.) e mi auguro (0.2) che anche voi che fate i giocatori, (.) facciate un discorso diverso. (...)

\section{Conclusions}

Adoption of a cultural perspective and a conversational methodology has enabled us to describe how the rhetorical manipulation of identity is a situated and social practice closely interconnected with other processes and activities and performed mainly through interactive discourse (i.e. by using language, this being the most powerful instrument of cultural mediation).

Our findings show that identity was a negotiated, rhetorically oriented and emergent outcome of the sport group's sociodiscursive interactions, and that it was used to achieve specific goals and to perform specific actions.

In pursuit of their rhetorical goals, the members of the team segmented their social world by allocating themselves and others to identity groups or categories functional to the presentation and sharing of a particular representation/interpretation of past, present and future events. Examples are provided by the manager, who "taught" a certain attitude by discursively creating a group of older players (as opposed to the younger ones); by the player who gave salience to a group corresponding to a section of the team in order to emphasise its responsibility for errors; by the manager, who marked the characteristics of specific players in order to imagine their role in forthcoming matches; and by the team, which analyzed itself in order to determine its strengths and weaknesses.

It has thus been shown that the identity game served to create a shared landscape in which the team members could meaningfully perform actions, take decisions, ask questions or make judgements.
One of the primary exigencies of social - and individual-life is to ensure the continuity of identities and interpretations of reality while also being able to introduce novelties and to cope with desired or imposed changes. For groups, and sport teams as well, this entails the constant sharing of information about the past and the planning of new courses of action, while respecting the complex array of roles, responsibilities and specialist practices unevenly distributed among the various team members and in the socio-physical setting in which they act.

The 'embeddedness' of identity negotiation practices in the characteristic and meaningful activities of a sport group (rather than its existence as a cognitive and individual phenomenon) is visible only if we adopt a sequential analysis of interactive data such as those presented here. Were we instead to adopt identity-focused interviews or standardized scales, we would more easily find clearly-defined borders of an abstract and generalized identity (identity construct), but we would necessarily be unable to determine how identity construction and manipulation emerge from, and are continuously shaped by, the ongoing construction of a group's situated social-discursive practices. Our results consequently confirm the usefulness of primary conversational data (transcripts of the discourse of social actors) for analysis of the evolution and moment-by-moment construction of identity rhetoric. We believe that such an epistemological and methodological choice may be applied to investigate, besides the theme of identity negotiation, how other psychological phenomena in sport groups emerge interactively.

\section{References}

Anderson, C. B. (2004). Athletic identity and its relation to exercise behavoir: Scale development and initial validation. Journal of Sport \& Exercise Psychology, 26, 39-56.

Antaki, C. \& Widdicombe, S. (Eds.) (1998). Identities in Talk. London: Sage.

Billig, M. (1987). Arguing and thinking. A rethorical approach to social psychology. Cambridge: Cambridge University Press.

Bruner, J. (1990). Acts of meaning. four lectures on mind and culture. Cambridge, MA: Harvard University Press.

Cole, M. (1995). Culture and cognitive development: From cross- cultural research to creating systems of cultural mediation. Culture \& Psychology, 1, 25-54. doi:10.1177/1354067X9511003

Cox, A. E., \& Whaley, D. E. (2004). The Influence of task value, expec-tancies for success, and Identity on athletes' achievement behavoirs. Journal of Apllied Sport Psychology, 16, 103-117. doi:10.1080/10413200490437930

Curry, T. J., \& Weaner, J. S. (1987). Sport identity salience, committment and the involvment of self in role: Measurement issues. Sociology of Sport Journal, 4, 280-288.

Edwards (1998). The relevant thing about Her: Social identity categories in use. In C. Antaki and S. Widdicombe(Eds.), Identities in Talk (pp. 15-33). London: Sage.

Fasulo A., \& Zucchermaglio C. (2002). My selves and I: Identity markers in work meeting talk. Journal of Pragmatics, 34, 1119-1144. doi:10.1016/S0378-2166(01)00051-0

Fasulo, A., \& Zucchermaglio C. (2008). Narratives in the workplace: Facts, fiction and canonicity. Text and Talk, 28, 351-376. doi:10.1515/TEXT.2008.017

Finlay, S. J., Faulkner, G. (2003). Actually I was the Star: Managing Attributions in Conversation. URL (last checked January 2003) http://www.qualitative-research.net/index.php/fqs/article/view/745 
Goffman, E. (1959). The presentation of self in everyday life. Garden City, New York: Doubleday.

Goodwin C., \& Goodwin, M. (2003). Participation. In A. Duranti (Ed.), A companion to linguistic anthropology (pp. 222-244). Oxford: Basil Blackwell.

Harré, R. (1989). Metaphysics and methodology: Some prescriptions for social psychological research. European Journal of Social Psychology, 19, 439-453. doi:10.1002/ejsp.2420190511

Harré, R., \& Van Langenhove, L. (1991). Varieties of positioning. Journal for the Theory of Social Behaviour, 21, 393-408. doi:10.1111/j.1468-5914.1991.tb00203.x

Hogg M. A., \& Hardie E. A. (1991). Social attraction, personal attraction and self-categorization: A field study. Personality and Social Psychology Bulletin, 17, 175-180. doi:10.1177/014616729101700209

Hogg, M. A. (1996). Social identity, self-categorization, and the small group. In E. H. Witte and J. H. Davis (Eds.), Understanding group behaviour (pp. 227-253). Mahwah, NJ: Erlbaum.

Jefferson, G. (1989). Preliminary notes on a possible metric which provides for a "standard maximum" silence of approximately one second in conversation. In D. Roger and P. Bull (Eds.), Conversation: an interdisciplinary perspective (pp. 156-197). Clevedon: Multilingual Matters.

Killeva-Jones, L. A. (2005). Identity structure, role discrepancy and psychological adjustment in male college students-athletes. Journal of Sport Behavior, 28, 167-185.

Locke, A. (2004). Accounting for success and failure: A discursive psychological approach to sport talk. Quest, 56, 302-320.

MacClancy, J. (1996). Sport, identity and ethnicity. US: Berg.

Muhlhausler, P, \& Harré, R. (1990). Pronouns and people: The linguistic construction of social and personal identity. Oxford: Basil Blackwell Pub.

Ochs, E., Gonzales, P., \& Jacoby, S. (1996). "When I come down I'm in the domain state": Grammar and graphic representation in the interpretative activity of physicists. In E. A. Schlegoff, E. Ochs and S. A. Thompson (Eds.), Interaction and grammar (pp. 328-369). Cambridge: Cambridge University Press.

doi:10.1017/CBO9780511620874.007
Perkins D. N. (1993). Person: Plus: a distributed view of thinking and learning. In G. Salomon (Ed.), Distributed cognition: psychological and educational considerations (pp. 88-111). Cambridge: Cambridge University Press

Robert, R. S. (1999). Anthropology, sport and culture. New York, NY: Bergin \& Garvey.

Sacks, H. (1992). Lectures on conversations. G. Jefferson (Ed.). Oxford: Basil Balckwell.

Schlegoff, E. A., Ochs, E., \& Thompson, S. A. (1996). Interaction and Grammar. Cambridge: Cambridge University.

Schmid, J., \& Seiler, R., (2003). Identity in high-performance sport; psychometric investigations with German language adaptation of the Athletic Identity Measurement Scale (AIMS-D). Diagnostica, 49, 176-183. doi:10.1026//0012-1924.49.4.176

Sparkes, A. C. (1996). The fatal flaw: A narrative of the fragile body-self. Qualitative Inquiry, 2, 463-494. doi: $10.1177 / 107780049600200405$

Sparkes, A. C. (1997). Ethnographic fiction and representing the absent Other. Sport, Educatioin and Society, 2, 25-40. doi: $10.1080 / 1357332970020102$

Sparkes, A. C. (2002). Telling tales in sport and physical activithy: A qualitative journey. Champaign, IL: Human Kinetics Press.

Thiele, J. (2003). Ethnographic perspectives in sport science in Germany. Status Quo and Developmental Potentials. Forum Qualitative Social Research, 4, 1.

Wenger, E. (1998). Communities of practice. Learning, meaning and identity. Cambridge, Mass.: Cambridge University Press.

Widdicombe, S. (1998). Identity as an analyst's and a participant's resource. In C. Antaki and S. Widdicombe, (Eds.), Identities in Talk (pp. 87-106). London: Sage.

Zimmerman, D. H. (1998). Identity, Context and Interaction. In C. Antaki and S. Widdicombe, (Eds.), Identities in Talk (pp. 87-106). London: Sage.

Zucchermaglio, C. (2005). Who wins and who loses: The rethorical manipulation of social identities in a soccer team. Group Dynamics: Theory, Research and Practice, 9, 219-238. doi:10.1037/1089-2699.9.4.219 